\title{
Genetic Variation Screening of TNNT2 Gene in a Cohort of Patients With Hypertrophic and Dilated Cardiomyopathy
}

\author{
M. JÁCHYMOVÁ ${ }^{1}$, A. MURAVSKÁ ${ }^{1}$, T. PALEČEK ${ }^{2}$, P. KUCHYNKA ${ }^{2}$, H. ŘEHÁKOVÁ ${ }^{1}$, \\ S. MAGAGE ${ }^{2}$, A. KRÁL ${ }^{2}$, T. ZIMA ${ }^{1}$, K. HORKÝ ${ }^{2}$, A. LINHART ${ }^{2}$ \\ ${ }^{1}$ Institute of Clinical Chemistry and Laboratory Diagnostics, First Faculty of Medicine and General \\ University Hospital, Charles University, Prague, Czech Republic, ${ }^{2}$ Second Department of Internal \\ Medicine - Clinical Department of Cardiology and Angiology, First Faculty of Medicine and \\ General University Hospital, Charles University, Prague, Czech Republic
}

Received February 1, 2011

Accepted October 17, 2011

On-line January 31, 2012

\section{Summary}

Mutations in troponin T (TNNT2) gene represent the important part of currently identified disease-causing mutations in hypertrophic (HCM) and dilated (DCM) cardiomyopathy. The aim of this study was to analyze TNNT2 gene exons in patients with $\mathrm{HCM}$ and DCM diagnosis to improve diagnostic and genetic consultancy in affected families. All 15 exons and their flanking regions of the TNNT2 gene were analyzed by DNA sequence analysis in 174 patients with HCM and DCM diagnosis. We identified genetic variations in TNNT2 exon regions in 56 patients and genetic variations in TNNT2 intron regions in 164 patients. Two patients were found to carry unique mutations in the TNNT2 gene. Limited genetic screening analysis is not suitable for routine testing of disease-causing mutations in patients with HCM and DCM as only individual mutation-positive cases may be identified. Therefore, this approach cannot be recommended for daily clinical practice even though, due to financial constraints, it currently represents the only available strategy in a majority of cardio-centers.

\section{Key words}

Cardiomyopathy - Genetic variations (mutation, polymorphism, deletion) $\bullet$ TNNT2 • Gene

\section{Corresponding author}

A. Muravská, Institute of Clinical Chemistry and Laboratory Diagnostics, First Faculty of Medicine, Charles University and General University Hospital, Na Bojišti 3, 12000 Prague 2, Czech Republic. Fax:+420224964219. E-mail: alexa.german@gmail.com

\section{Introduction}

Cardiomyopathies are generally defined as myocardial disorders in which the heart muscle is structurally and functionally abnormal, in the absence of coronary artery disease, hypertension, valvular disease and congenital heart disease sufficient to cause the observed myocardial abnormality (Elliott et al. 2008). According to the morphological and functional phenotype the diagnosis of hypertrophic and dilated cardiomyopathy can be established. Hypertrophic cardiomyopathy (HCM) is an autosomal dominant cardiac disorder (Marian and Roberts 1995) with a prevalence of $0.2 \%$ in the general population (Richard et al. 2003). More than $70 \%$ of HCM cases are familial (Friedrich et al. 2009). Hypertrophic cardiomyopathy represents one of the the most frequent causes of sudden cardiac death in the young, especially in competitive athletes (Erdmann et al. 2003, Ehlermann et al. 2008) and a major cause of morbidity and mortality in the elderly (Michels et al. 2007).

The major morphological features of the disease are left ( \pm right) ventricular hypertrophy with predominant involvement of the interventricular septum (Fokstuen et al. 2008), myocyte disarray and interstitial myocardial fibrosis (Friedrich et al. 2009). However, the mechanism of HCM development on the cellular and molecular level has not yet been fully described. Myocardial hypertrophy could develop as a result of reduced contractile function. However, studies conducted 
in humans and animals with sarcomeric protein mutations showed that the velocity and force of myocyte contraction were in fact increased (Redwood et al. 1999). Furthermore, some authors have suggested that abnormal myocardial bioenergetics importantly contribute to the HCM phenotype (Ashrafian et al. 2003).

Dilated cardiomyopathy (DCM) is an inherited or acquired disease characterized by left ventricular dilatation and reduced systolic function. DCM represents the third most common cause of heart failure and the most frequent cause of heart transplantation. It accounts for approximately $3 \%$ of all sudden cardiac deaths in young athletes (Gilbert et al. 1993, Maron et al. 1996, Kamisago et al. 2000). Importantly, 30-50 \% of all cases are diagnosed as a familial form of DCM (Burkett and Hershberger 2005).

Recent studies have reported 27 genes associated with HCM and 32 genes, involving 2 X-linked genes, associated with DCM (reviewed in Tester et al. 2011 and Hershberger et al. 2011). In the vast majority of cases these genes encode for sarcomeric contractile proteins (García-Castro et al. 2009, Landstrom et al. 2011): $\beta$-myosin heavy chain (MYH7), myosin binding protein $\mathrm{C}$ (MYBPC3), troponin $\mathrm{T}$ (TNNT2), troponin I (TNNI3), cardiac $\alpha$-actin (ACTC) and $\alpha$-tropomyosin (TPM1). Additionally, genes encoding components of the cardiac Z-disk, calcium $\left(\mathrm{Ca}^{2+}\right)$-handling, and regulatory proteins have been recently associated with cardiomyopathies (Landstrom et al. 2010, Tester et al. 2011). Nearly all of the mutations $(86 \%)$ are single nucleotide mutations, which can lead to the changes in protein chains. Remaining mutations include small in-frame insertions or deletions and rarely large deletions (Fokstuen et al. 2008).

The TNNT2 gene (OMIM number *191045) encodes the thin-filament contractile protein cardiac troponin $\mathrm{T}$, which links the troponin complex to tropomyosin in the sarcomere (García-Castro et al. 2003). The gene containing 15 exons is located on chromosome $1 \mathrm{q} 32$, and comprises $25 \mathrm{~kb}$ of genome. TNNT2 mutations are responsible for about $15 \%$ of all cases of familial HCM (Sehnert et al. 2002). MYH7 and TNNT2 gene mutations also represent common genetic causes of DCM. According to the recent studies, MYH7 and TNNT2 mutations are responsible for about 4-6\% and $3 \%$ of cases of familial DCM, respectively (Hershberger et al. 2009).

One of the significant features of cardiomyopathies is a wide phenotypic heterogenity even within one family with the same mutation (Michels et al. 2007, Friedrich et al. 2009). Some genetic analyses have also revealed the presence of clinically healthy individuals carrying the mutant allele (Forissier et al. 1996). Moreover, significant proportion of the cardiomyopathy population remains genotype-negative with no biomarker for, or mechanistic explanation of, their disease process. These findings indicate that in addition to the responsible gene, environmental factors and other genetic factors (genes/polymorphisms) can modulate the phenotypic expression of the disease (Forissier et al. 1996, Friedrich et al. 2009, Landstrom et al. 2010).

In the present study, we analyzed TNNT2 exons in patients with HCM and DCM diagnosis to improve diagnostic and genetic consultancy in affected families.

\section{Methods}

\section{Patients}

174 unrelated Caucasian patients with HCM $(n=84)$ and DCM $(n=90)$, mean age $48.4 \pm 15.1$ years, were evaluated in the Clinical Department of Cardiology and Angiology, First Faculty of Medicine and General University Hospital, Charles University, Prague, Czech Republic, and were included in this single center study. The diagnosis of HCM and DCM was based on current recommendations (Elliott et al. 2008). The clinical characteristic of our patients is provided in Table 1 .

Table 1. Clinical characteristic of patients with HCM and DCM.

\begin{tabular}{lcc}
\hline & $\begin{array}{c}\text { Hypertrophic } \\
\text { cardiomyopathy } \\
(\mathbf{n}=\mathbf{8 4})\end{array}$ & $\begin{array}{c}\text { Dilated } \\
\text { cardiomyopathy } \\
(\mathbf{n = 9 0 )}\end{array}$ \\
\hline $\begin{array}{l}\text { Age (years) } \\
\text { Males }\end{array}$ & $51 \pm 13$ & $48 \pm 17$ \\
$\begin{array}{l}\text { Positive family } \\
\text { history of }\end{array}$ & $64(76 \%)$ & $72(80 \%)$ \\
cardiomyopathy & $29(35 \%)$ & $11(12 \%)$ \\
NYHA class & $2.0 \pm 0.7$ & $1.5 \pm 0.8$ \\
$\begin{array}{l}\text { Arterial } \\
\text { hypertension }\end{array}$ & $40(48 \%)$ & $39(43 \%)$ \\
$\begin{array}{l}\text { Diabetes mellitus } \\
\text { Smoking }\end{array}$ & $9(11 \%)$ & $14(16 \%)$ \\
\hline
\end{tabular}

Data are expressed as mean \pm standard deviation or as a number and percentage of the subjects. 
Table 2. Primers and PCR-RFLP conditions - TNNT2 polymorphisms screening.

\begin{tabular}{ccc}
\hline Polymorphism & I79N & R92W \\
\hline Primer sequence, $5^{\prime}-3^{\prime}$ & & \\
forward & & \\
reverse & atg ggg ctg atg ctg act at & cac cct ctc ctc tgg ac \\
Annealing $T\left({ }^{\circ} \mathrm{C}\right)$ & gcc caa ggt cac aaa atc tc & ctc aca aaa ggg atg gag ga \\
Restriction enzyme & 59.5 & MspI \\
Product size $(b p)$ & MboI & 247 \\
Allele (fragment sizes) $(b p)$ & 180 & $\mathrm{C}(175+72) / \mathrm{T}(247)$ \\
\hline
\end{tabular}

One hundred and two unrelated healthy Caucasian subjects (mean age $51 \pm 10$ years, 52 males $(51 \%)$ served as controls.

The study was performed in accordance with principles of the Declaration of Helsinki and approved by the Institutional Ethical Committee. All patients gave their informed consent prior to entering the study.

\section{Samples}

Blood samples were collected via puncture of the cubital vein. Tubes with ethylene diamine tetraacetic acid were used for DNA analysis. Blood samples were stored at $4{ }^{\circ} \mathrm{C}$ and isolation of DNA was performed by a modified salting out procedure according to Miller et al. (1988) within a week of collection.

\section{TNNT2 screening}

First, screening for mutations in TNNT2 exons $7(\mathrm{I} 76 \mathrm{~N})$ and $8(\mathrm{R} 92 \mathrm{~W})$ was done using restriction fragment length polymorphism (RFLP) analysis.

The DNA was amplified by polymerase chain reaction $(\mathrm{PCR})$ with primers and annealing temperatures summarized in Table 2. PCR product was then digested with corresponding restriction endonuclease (Table 2) according to the manufacturer's recommended protocol. Restriction fragments were separated by electrophoresis in $3 \%$ agarose gel and visualized in UV light after ethidium bromide staining. Results were confirmed by DNA sequencing.

The primers were predicted by Primer3 Input (http://frodo.wi.mit.edu/) and restriction enzymes were assessed using NebCutter V2.0 (http://tools.neb.com/ NEBcutter2).

\section{TNNT2 sequencing}

The entire coding sequences of TNNT2 gene were amplified by PCR with primers and annealing temperatures summarized in Table 3. Products were separated by electrophoresis in $2 \%$ agarose gel, excised from the gel and purified with spin columns (NucleoSpin Extract II, Macherey-Nagel). Both strands of purified DNA were then sequenced in a CEQ 8000 genetic analysis system (Beckman Coulter) according to the manufacturer's protocol. The primers for TNNT2 exons 9, 11, 12, 13 and 14 were predicted by Primer3 Input (http://frodo.wi.mit.edu/), while the remainder was designed according to Seidmann et al. (www.cardiogenomics.org).

\section{Results}

The mutations I79N, R92W, R92G, R92L in the TNNT2 gene were screened by RFLP analysis and results were then confirmed by DNA sequencing. Within our study group, which consisted of 174 patients (84 patients with HCM and 90 patients with DCM), we identified one mutation in R92W in exon 8 of the TNNT2 gene in a patient with HCM.

We additionally examined all of the 15 exons and their flanking regions of the TNNT2 gene in the same group of patients. Using DNA sequence analysis to investigate polymorphisms, small deletions and new mutations and we found genetic variations in exon regions in 56 patients and genetic variations in intron regions in 164 patients (Table 4). We confirmed the presence of a unique mutation in $\mathrm{R} 92 \mathrm{~W}$ (exon 8) in a single HMC patient and another unique mutation A172S (exon 10) in a DCM patient. Moreover, we analyzed mutations R92W in exon 8 and A172S in exon 10 in the control group consisted of 102 healthy individuals to confirm that these mutations are not associated with healthy subjects. 
Table 3. Primers and PCR conditions - TNNT2 sequencing.

\section{Primers predicted by Primer3 Input}

Primer sequence $5^{\prime}-3^{\prime}$

Exon 9

Exon 11

Exon 12

Exon 13

Exon 14 ggc acc att get tca aga ct tcc caa agt get ggg att ac cet get gta acc ctc aga cc cag ccc aat ctc ttc act cc

tgt ggc agg aag aag agc at tgc cat ggg aaa ata tgt ga gaa ctt tgc cet ggc agt c cag gga cct gca gca gta $\mathrm{tt}$

ctc ctt ctc ctc ctg cac tg agg agc cag aga agg aaa cc
Annealing T $\left({ }^{\circ} \mathrm{C}\right)$

Product size (bp)

60.1

369

59.8

284

60.3

365

60.5

398

60.0

301

\section{Primers according to Seidmann et al.}

Primer sequence 5' - 3'

Annealing $\mathrm{T}\left({ }^{\circ} \mathrm{C}\right)$

66.8

358

Exon 1

gct gca tgt ggt gtc act atc tcc c cac agc tac ttc tac cca gaa tcc

Exon $2+3$ aca agg gaa aag aaa ggg gga tta agt gag gag cag gga cag atg agc

Exon $4+5$ tgt ggg cat tct cet cca aag ctg

Exon 6 cac tgt gca gat ggg gaa atg ga

Exon $7+8$ gga tca ggc cet gec tgt cet gac a gga tga gac aga ctg gcc atc ag

Exon $9+10$ gga ggc cgg gca cca ttc ttc aag gga cet gac cta aag tct acc tgc

Exon $14+15$ cat gag tgg ggc ctg ctt ctt c tcc tet ctc cta gge ctc tgc $\mathrm{t}$

acc tgg acc tga gec agt cta gtt tct ctc tct ctc tga

Table 4. Genetic variations (mutations, polymorphisms, small deletions) of the TNNT2 gene in HCM and DCM patients.

\begin{tabular}{|c|c|c|c|c|c|}
\hline Gene & Exon & Amino acid position & $\begin{array}{c}\text { dbSNP access } \\
\text { number }^{1}\end{array}$ & DNA variation & $\begin{array}{c}\text { Number of } \\
\text { patients }\end{array}$ \\
\hline \multirow[t]{9}{*}{ TNNT2 } & 7 & S79S & rs3729845 & $\mathrm{aTCG} \rightarrow \mathrm{TCA}$ & 9 \\
\hline & 8 & R92W & CM971501 & $\mathrm{cCGG} \rightarrow \mathrm{TGG}$ & 1 \\
\hline & & I116I & rs 3729547 & $\mathrm{ATC} \rightarrow \mathrm{ATT}$ & 41 \\
\hline & 10 & A172S & CM043107 & $\mathrm{gGCC} \rightarrow \mathrm{TCC}$ & 1 \\
\hline & 13 & K260R & rs3730238 & $\mathrm{gAAG} \rightarrow \mathrm{AGG}$ & 4 \\
\hline & Intron & & & & \\
\hline & 1 & - & rs 868407 & $\mathrm{C} \rightarrow \mathrm{T}$ & 74 \\
\hline & 2 & - & rs45533739 & deletion CTTCT & 70 \\
\hline & 12 & - & rs2275861 & $\mathrm{C} \rightarrow \mathrm{T}$ & 20 \\
\hline
\end{tabular}

${ }^{1} \mathrm{dbSNP}$ access number: polymorphisms and deletions are characterized by rs number, mutations by CM number. 
Table 5. TNNT2 gene polymorphisms and small deletions in HCM patients.

\begin{tabular}{|c|c|c|c|c|c|c|}
\hline \multirow[b]{2}{*}{ Exon 7} & \multirow[b]{2}{*}{ S79S } & \multicolumn{3}{|c|}{ Genotypes (\%) } & \multicolumn{2}{|c|}{ Allele frequencies } \\
\hline & & GG & GA & $\mathrm{AA}$ & $\mathrm{G}$ & A \\
\hline & & 89 & 11 & 0 & 0.946 & 0.054 \\
\hline \multirow[t]{2}{*}{ Exon 8} & I116I & TT & $\mathrm{CT}$ & $\mathrm{CC}$ & $\mathrm{T}$ & $\mathrm{C}$ \\
\hline & & 45 & 40 & 15 & 0.653 & 0.347 \\
\hline \multirow[t]{2}{*}{ Exon 13} & K260R & $\mathrm{AA}$ & $\mathrm{AG}$ & GG & $\mathrm{A}$ & $\mathrm{G}$ \\
\hline & & 95 & 5 & 0 & 0.975 & 0.025 \\
\hline \multirow[t]{2}{*}{ Intron 1} & $\mathrm{C} / \mathrm{T}$ & $\mathrm{TT}$ & $\mathrm{CT}$ & $\mathrm{CC}$ & $\mathrm{T}$ & $\mathrm{C}$ \\
\hline & & 49 & 39 & 12 & 0.685 & 0.315 \\
\hline \multirow[t]{2}{*}{ Intron 2} & deletion CTTCT & ++ & +- & -- & + & - \\
\hline & & 34 & 49 & 17 & 0.589 & 0.411 \\
\hline \multirow[t]{2}{*}{ Intron 12} & $\mathrm{C} / \mathrm{T}$ & TT & $\mathrm{CT}$ & $\mathrm{CC}$ & $\mathrm{T}$ & $\mathrm{C}$ \\
\hline & & 77 & 23 & 0 & 0.883 & 0.117 \\
\hline
\end{tabular}

The frequencies of remaining TNNT2 gene polymorphisms from Table 4 correlated with data in the SNP database (dbSNP) of the National Centre for Biotechnology Information (Table 5).

\section{Discussion}

In our study, we analyzed the entire coding sequences of the TNNT2 gene (15 exons, 6000 nucleotides) in patients with HCM and DCM. Our aim was to improve diagnostic and genetic consultancy in affected families. Within our study population consisting of 174 patients, we were able to identify two patients with unique mutations in TNNT2 gene (one with HCM and one with DCM) and none of these mutations were presented in our control group of healthy subjects.

The results of our study clearly show both advantages and disadvantages of employing routine clinical genetic screening in subjects suffering from cardiomyopathies. The identification of a unique mutation responsible for phenotypic expression of cardiomyopathy in a given proband requires that genetic analyses be performed on the patient's immediate relatives. Mutationfree relatives will not require regular clinical screening and can be assured that their children will not be affected by this type of cardiomyopathy. On the other hand, the presence of the disease-causing mutation should prompt more frequent check-ups of the affected relative in order to identify early phenotypic expression of the disease and thereby improve the management of the affected person (Charron et al. 2010). Importantly, the identification of the mutation in a proband and, possibly, in their relatives requires that they be given clinical genetic counselling to explain of the risk of transmitting the mutation to their children with the possibility of prenatal genetic diagnosis (Charron et al. 2010).

There are clear limitations in the feasibility and practicality of screening for mutations in only one gene. In our opinion, these limitations outweigh the above listed advantages. According to current recommendations, the main genes of interest in $\mathrm{HCM}$ and DCM for mutation screening in routine practice comprise both MYH7 and TNNT2 genes (Hershberger et al. 2009). The mutations in these two genes represent the majority of currently identifiable disease-causing mutations of HCM and DCM (Fowler et al. 2009). However, genetic analysis as we have done, which is limited to only a small number of potentially involved exons, does not seem to be applicable. We were able to perform analysis of all 15 exons of TNNT2 gene, and we have found 2 unique TNNT2 mutations, one in an HCM patient and one in a DCM patient. However, this number is lower than the frequency of TNNT2 gene mutations in both cardiomyopathies as reported in current literature (Richard et al. 2003, Hershberger et al. 2009).

We believe that the rather general definition of DCM in our study cohort may explain this discrepancy, as subjects with chronic myocarditis or other acquired forms of cardiomyopathy were likely included. In a more specifically defined population of patients with otherwise unexplained, idiopathic DCM, the prevalence of TNNT2 mutations could be higher than what we observed. 
Nevertheless, this fact again underscores the important limitations of our approach based on analyses of only a limited number of exons of disease-related mutations. Due to limited financial resources, we focused only on TNNT2 gene exons. This strategy was employed since TNNT2 mutations are thought to be responsible for an important form of HCM associated with highly increased risk of sudden cardiac death (Watkins et al. 1995).

Nevertheless, even in highly specialized centers for genetic diagnostics of cardiomyopathies, testing is usually limited to the most common causative genes (Cowan et al. 2008). This approach may change in the near future as more cost-effective methods capable of wide genome screening, such as chip-based or next generation sequencing, become available.

In conclusion, limited genetic screening analysis is not suitable for routine testing of disease-causing mutations in patients with HCM and DCM as only individual mutation-positive cases may be identified. Therefore, this approach cannot be recommended for daily clinical practice even though, due to financial constraints, it currently represents the only available strategy in the majority of cardio-centers. More costeffective methods enabling wide genome screening are promising and should be implemented in genetic analyses of cardiomyopathies in the near future.

\section{Conflict of Interest}

There is no conflict of interest.

\section{Acknowledgements}

The authors thank William E. Louch, Ph.D., for proofreading assistance. The study was supported by research projects MZO 0000VFN2005 (0000064165).

\section{References}

ASHRAFIAN H, REDWOOD C, BLAIR E, WATKINS H: Hypertrophic cardiomyopathy: a paradigm for myocardial energy depletion. Trends Genet 19: 263-268, 2003.

BURKETT EL, HERSHBERGER RE: Clinical and genetic issues in familial dilated cardiomyopathy. J Am Coll Cardiol 45: 969-981, 2005.

CHARRON P, ARAD M, ARBUSTINI E, BASSO C, BILINSKA Z, ELLIOTT P, HELIO T, KEREN A, MCKENNA WJ, MONSERRAT L, PANKUWEIT S, PERROT A, RAPEZZI C, RISTIC A, SEGGEWISS H, VAN LANGEN I, TAVAZZI L, EUROPEAN SOCIETY OF CARDIOLOGY WORKING GROUP ON MYOCARDIAL AND PERICARDIAL DISEASES: Genetic counselling and testing in cardiomyopathies: a position statement of the European Society of Cardiology Working Group on Myocardial and Pericardial Diseases. Eur Heart J 31: 2715-2726, 2010.

COWAN J, MORALES A, DAGUA J, HERSHBERGER RE: Genetic testing and genetic counseling in cardiovascular genetic medicine: overview and preliminary recommendations. Congest Heart Fail 14: 97-105, 2008.

EHLERMANN P, WEICHENHAN D, ZEHELEIN J, STEEN H, PRIBE R, ZELLER R, LEHRKE S, ZUGCK C, IVANDIC BT, KATUS HA: Adverse events in families with hypertrophic or dilated cardiomyopathy and mutations in the MYBPC3 gene. BMC Med Genet 9: 95, 2008.

ELLIOTT P, ANDERSSON B, ARBUSTINI E, BILINSKA Z, CECCHI F, CHARRON P, DUBOURG O, KÜHL U, MAISCH B, MCKENNA WJ, MONSERRAT L, PANKUWEIT S, RAPEZZI C, SEFEROVIC P, TAVAZZI L, KEREN A: Classification of the cardiomyopathies: a position statement from the European Society Of Cardiology Working Group on Myocardial and Pericardial Diseases. Eur Heart J 29: 270-276, 2008.

FOKSTUEN S, LYLE R, MUNOZ A, GEHRIG C, LERCH R, PERROT A, OSTERZIEL KJ, GEIER C, BEGHETTI M, MACH F, SZTAJZEL J, SIGWART U, ANTONARAKIS SE, BLOUIN JL: A DNA resequencing array for pathogenic mutation detection in hypertrophic cardiomyopathy. Hum Mutat 29: 879-885, 2008.

FORISSIER JF, CARRIER L, FARZA H, BONNE G, BERCOVICI J, RICHARD P, HAINQUE B, TOWNSEND PJ, YACOUB MH, FAURÉ S, DUBOURG O, MILlAIRE A, HAGÈGE AA, DESNOS M, KOMAJDA M, SCHWARTZ K: Codon 102 of the cardiac troponin $\mathrm{T}$ gene is a putative hot spot for mutations in familial hypertrophic cardiomyopathy. Circulation 94: 3069-3073, 1996.

FOWLER SJ, NAPOLITANO C, PRIORI SG: The genetics of cardiomyopathy: genotyping and genetic counseling. Curr Treat Options Cardiovasc Med 11: 433-446, 2009. 
FRIEDRICH FW, BAUSERO P, SUN Y, TRESZL A, KRÄMER E, JUHR D, RICHARD P, WEGSCHEIDER K, SCHWARTZ K, BRITO D, ARBUSTINI E, WALDENSTRÖM A, ISNARD R, KOMAJDA M, ESCHENHAGEN T, CARRIER L, FOR THE EUROGENE HEART FAILURE PROJECT: A new polymorphism in human calmodulin III gene promoter is a potential modifier gene for familial hypertrophic cardiomyopathy. Eur Heart J 30: 1648-1655, 2009.

GARCÍA-CASTRO M, REGUERO JR, BATALLA A, DÍAZ-MOLINA B, GONZÁLEZ P, ALVAREZ V, CORTINA A, CUBERO GI, COTO E: Hypertrophic cardiomyopathy: low frequency of mutations in the beta-myosin heavy chain (MYH7) and cardiac troponin T (TNNT2) genes among Spanish patients. Clin Chem 49: 1279$1285,2003$.

GARCÍA-CASTRO M, COTO E, REGUERO JR, BERRAZUETA JR, ALVAREZ V, ALONSO B, SAINZ R, MARTÍN M, MORÍS C: Mutations in sarcomeric genes MYH7, MYBPC3, TNNT2, TNNI3, and TPM1 in patients with hypertrophic cardiomyopathy. Rev Esp Cardiol 62: 48-56, 2009.

GILBERT EM, DI LENARDA A, O'CONNELL JB: Dilated cardiomyopathy: prognosis and management. In: Cardiomyopathies: Realisations and Expectations. J GOODWIN, E OLSEN (eds), Springer-Verlag, Heidelberg, 1993, pp 46.

HERSHBERGER RE, COWAN J, MORALES A, SIEGFRIED JD: Progress with genetic cardiomyopathies: screening, counseling, and testing in dilated, hypertrophic, and arrhythmogenic right ventricular dysplasia/cardiomyopathy. Circ Heart Fail 2: 253-261, 2009.

HERSHBERGER RE, SIEGFRIED JD: Update 2011: clinical and genetic issues in familial dilated cardiomyopathy. J Am Coll Cardiol 57: 1641-1649, 2011.

KAMISAGO M, SHARMA SD, DEPALMA SR, SOLOMON S, SHARMA P, MCDONOUGH B, SMOOT L, MULLEN MP, WOOLF PK, WIGLE ED, SEIDMAN JG, SEIDMAN CE: Mutations in sarcomere protein genes as a cause of dilated cardiomyopathy. N Engl J Med 343: 1688-1696, 2000.

LANDSTROM AP, ACKERMAN MJ: Mutation type is not clinically useful in predicting prognosis in hypertrophic cardiomyopathy. Circulation 122: 2441-2449, 2010.

MARIAN AJ, ROBERTS R: Recent advances in the molecular genetics of hypertrophic cardiomyopathy. Circulation 92: 1336-1347, 1995.

MARON BJ, THOMPSON PD, PUFFER JC, MCGREW CA, STRONG WB, DOUGLAS PS, CLARK LT, MITTEN MJ, CRAWFORD MH, ATKINS DL, DRISCOLL DJ, EPSTEIN AE: Cardiovascular preparticipation screening of competitive athletes. A statement for health professionals from the Sudden Death Committee (clinical cardiology) and Congenital Cardiac Defects Committee (cardiovascular disease in the young), American Heart Association. Circulation 94: 850-856, 1996.

MICHELS M, HOEDEMAEKERS YM, KOFFLARD MJ, FROHN-MULDER I, DOOIJES D, MAJOORKRAKAUER D, TEN CATE FJ: Familial screening and genetic counselling in hypertrophic cardiomyopathy: the Rotterdam experience. Neth Heart J 15: 184-190, 2007.

MILLER SA, DYKES DD, POLESKY HF: A simple salting out procedure for extracting DNA from human nucleated cells. Nucleic Acids Res 16: 1215, 1988.

REDWOOD CS, MOOLMAN-SMOOK JC, WATKINS H: Properties of mutant contractile proteins that cause hypertrophic cardiomyopathy. Cardiovasc Res 44: 20-36, 1999.

RICHARD P, CHARRON P, CARRIER L, LEDEUIL C, CHEAV T, PICHEREAU C, ERDMANN J, DAEHMLOW S, WISCHKE S, SENYUVA M, WERNER U, RAIBLE J, TANIS N, DYACHENKO S, HUMMEL M, HETZER R, REGITZ-ZAGROSEK V: Mutation spectrum in a large cohort of unrelated consecutive patients with hypertrophic cardiomyopathy. Clin Genet 64: 339-349, 2003.

SEHNERT AJ, HUQ A, WEINSTEIN BM, WALKER C, FISHMAN M, STAINIER DY: Cardiac troponin T is essential in sarcomere assembly and cardiac contractility. Nat Genet 31: 106-110, 2002.

TESTER DJ, ACKERMAN MJ: Genetic testing for potentially lethal, highly treatable inherited cardiomyopathies/channelopathies in clinical practice. Circulation 123: 1021-1037, 2011.

WATKINS H, MCKENNA WJ, THIERFELDER L, SUK HJ, ANAN R, O'DONOGHUE A, SPIRITO P, MATSUMORI A, MORAVEC CS, SEIDMAN JG, SEIDMAN CE: Mutations in the genes for cardiac troponin T and alpha-tropomyosin in hypertrophic cardiomyopathy. N Engl J Med 332: 1058-1064, 1995. 